\title{
Global Value Chains, Emerging Markets, and IB Education
}

\section{Robert Grosse, Thunderbird School of Global Management, USA}

Having served as Dean of business schools on two continents and as a management educator in schools on three continents, I will address here international business (IB) teaching and the relevant themes that should be included in the curriculum in both general and specific contexts. Besides, I wrote an AIB Curriculum Survey about forty years ago, and have observed and participated in the development of IB curricula since then, so that I have reasonable knowledge about what we do. Having worked as one of the leaders of a major multinational bank for several years recently, I also have gained some perspective on what IB capabilities international firms need in their managers/leaders. This essay then speaks to one aspect of the evolving global economy and to the needs of IB graduates who will manage in this new world.

I will not suggest an appropriate IB domain or theoretical approach as Simon Collinson does in this issue but will offer a perspective that could be incorporated into any IB curriculum and that may be a useful organizing principle for teaching IB in many places. However, this perspective is only "provocative" in arguing that this issue needs to be recognized as we teach millennials and their successors in the internet age.

\section{The New Challenges}

What really is challenging us as IB scholars and teachers is that the demand for our product is not growing - at least not in the United States. Besides, what we teach can easily be incorporated in the "international" chapter and relevant parts of textbooks on marketing, economics, finance, management, strategy, and other disciplines, so that the demand for separate international business courses will not increase in the U.S. context. Our uniqueness is thus questioned and our "added value" is no longer clear. Even though we can point to the fact that cross-border business involves such major issues as cross-cultural management, government-business relations, and perhaps the arbitrage of costs and regulatory conditions, we still seem to be becoming a marginal rather than a core discipline. Because we are indeed cross-disciplinary, it is not possible to argue that there is one overarching theory of international business, even though Raymond Vernon's international product lifecycle and John Dunning's eclectic theory have been shining examples of theories that have included two or more of our functional disciplines. Fortunately, companies, students, and professors around the world recognize the importance of international business, and there is a growth of IB teaching in countries such as China and India, which are very large and rapidly growing markets for our field. So, what can we do to stake a better claim on relevance and even centrality in business analysis?

\section{Our Crucial Competences}

We need to pursue analyses of key issues in the world economy and society of today in order to build up our relevance and credibility. In addition, there is no doubt that we need to continue to pursue Thomas Kuhn's "normal science" by attacking interesting IB issues with solid methodologies and by coming up with useful conclusions. Still, we need to take our analyses to issues of major national and international concern. Originally, IB professors looked at U.S. international business and generally argued that international trade and investment should be encouraged, and that firms needed to deal credibly and legitimately with national governments. Now we should be staking our claim to understanding how China should be dealt with as a (mercantilist) source of FDI and exports and as a target market for foreign firms; and we should be analyzing employment patterns and opportunities in the United States and Europe as supply chains extend further into emerging markets and as technology eliminates manufacturing jobs (among other major issues).

We have progressed a long way from our early days in the 1960s, but there are plenty of big issues where we can still make a mark. Obviously in the United States of today, analyses of why exports and imports are economically very valuable is very important - especially in the context of such international trade agreements as NAFTA with Canada and Mexico. Besides, 
showing how FDI abroad supports the growth and wealth of the U.S. economy is needed once again. It does not matter that we have written about these issues in the past because today's environment requires new statements of the benefits of international business.

Beyond U.S. concerns, we have a global interest in the combined hegemony of the United States and China, and how it does and will affect international business. After the global crisis of 2007-2009, we have witnessed a much greater willingness of governments to intervene in financial and other markets: how does this development impinge on international business? A huge cultural and political issue is how governments deal with Islamic extremism and terrorism. This is a worldwide concern, and we, as IB experts, certainly should be able to offer useful perspectives on cross-cultural communication and management as well as on Middle East-European Union-United States relations and business.

These are just a few of the vital topics of concern to decision makers and policy makers today. If our field wants to build its credibility further, then we need to address these kinds of topics and carry out analyses that are as unbiased and generalizable as possible. From the beginning, the field of international business has been policy and strategy oriented, and this is an excellent time for us to focus on such concerns again.

\section{The New Global Vallue Chains}

One line of attack on key issues today rests on the fact that international business in the 21 st century largely operates in the context of global value chains (GVCs) through which firms from various nations provide production inputs, process/manufacture/produce/transport outputs, and sell them in a variety of countries. This reality leads to a need for international business analysts and educators to focus on the structure and functioning of these global value chains and to show firms how to position themselves to take advantage of opportunities in this environment. It also calls for government policy makers to recognize GVCs and support the development of domestic firms into key roles within these chains.

Just think of the much-cited value chain of the Apple iPhone, which spans five countries on three continents for its production - not to speak of sales of the phone, which are truly global.' Suppliers of components and inputs into the production of this phone come from the United States, Germany, Japan and Korea while assembly takes place in China. All of the companies involved are participants in the iPhone's global value chain, and opportunities exist for them to insert themselves into value chains of other products (e.g., different cell phones and other consumer electronics) as most of them do.

This is very different from the second half of the 20th century when more integrated MNEs operated in a world of higher transport and regulatory costs and when technology was more isolated before the arrival and diffusion of the Internet. The new situation means that firms in emerging markets are much more likely to find opportunities in the value chains as they become aware of the opportunities "out there."

To expand on this idea, and to ensure that small- and medium-sized firms are included in the discussion, think about the global value chain of a company involved in providing a service - namely, Amazon.com. This company offers a global marketplace through which companies and individuals can sell products or services to anyone via the internet. Without getting into detailing the technology underpinning Amazon. com's marketplace, suffice it to say that the company buys computers and network equipment to operate its global platform

\section{Figure 1. Amazon.com's Value Added Chain}
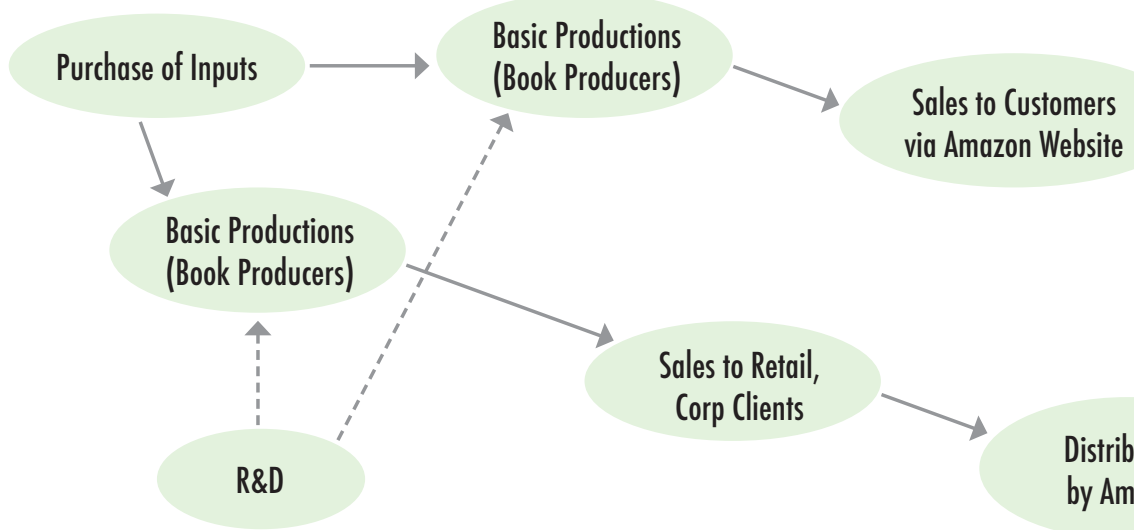

Distribution

by Amazon

Distribution by Publishers with Amazon Instructions

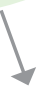

After-Sale Service 
where companies list their products and customers place their purchase orders. Then, Amazon operates a huge distribution network with transportation of its products either to its warehouses or directly from producer/supplier to customer. Thinking about Amazon's first product line - e.g., books - the global value chain looks something like its representation in Figure 1.

Amazon's value chain has two main lines of production and distribution. One goes through Amazon's own distribution system whereby Amazon buys from a book publisher, sells, and ships the book to a customer. The other line goes directly from the publisher to the consumer, with Amazon charging the producer a fee for delivering to the customer, for organizing the shipping, and for tax payment on the book.

In addition to its book value chain, Amazon sells and distributes tens of thousands of other products. If we consider Amazon's overall value chain, it would show purchases of inputs such as electronics, clothes, toys, and many other products from thousands of producers, the "production" of the service of connecting producers with consumers, and then purchases of delivery services from UPS and Fedex in addition to Amazon's own delivery service, to after-sale service offered to Amazon's millions of customers around the world.

Given that the value chain is a description of how business works today, it is open to theoretical approaches from many social sciences, and it readily fits into analyses of company strategy, location of business activities, cross-cultural management of employees, organization structures, and marketing planning. As noted above, the GVC perspective directly opens thinking and discussion of the incorporation of emerging markets into many if not most value chains, which is relevant in the $21 \mathrm{st}$ century when most growth in the world economy comes from this group of countries. And, as particularly relevant in the Amazon case, the GVC phenomenon demonstrates opportunities for small- and medium-sized enterprises to participate in such value chains.

\section{Future IB Teaching and Research about Vallue Chains}

What should IB teaching and research focus on? Clearly study is needed of how firms can best insert themselves into global value chains. Besides, MNEs with value chain members in emerging markets will need to pay more attention to social and political issues that historically were not as significant in the developed countries where the firms mostly operated. New policy challenges are likely to result from more protectionist or at least less globally-open policies in the United States and United Kingdom, based on recent votes in those countries. Hence, company managers will need to re-consider their networks of supply chain sources and transport links, which may become (slightly) more costly in the near future, and academics will need to give them guidance on risk management and alternative supply/value chain structures.

If new protectionism does indeed occur, it will require some new thinking by IB educators who have been fixated on the benefits of comparative advantage and free trade without adequately considering government policy in a sub-optimal world where countries cheat on free trade and companies employ monopolistic practices. IB educators will need to incorporate these developments into their teaching and writing. These issues relate not just to NAFTA and Brexit but also to existing protectionism - for example, in the U.S. trade with China where the relatively open United States faces a highly restrictive China, although academics continue to push for unilateral free trade on the part of the United States.

For IB scholars, handling these new realities should be a no-brainer - namely, that institutions matter and that free trade in a vacuum is different from the real trade that takes place. They should be looking for government policies that would maximize voters' well-being and for company strategies that take into account possible government actions to pursue nation-serving ends. To bear on these and other issues of great importance today, perspectives can be borrowed from disciplines ranging from organizational behavior to economic geography and from financial market analysis to consumer behavior.

\section{Endnotes}

'See the iPhone value chain reproduced in Grosse (2016: 5-6).

\section{References}

Grosse, R. 2016. Emerging markets: Strategies for competing in the global value chain. London: Kogan Page.

Robert Grosse (Robert.Grosse@thunderbird.asu.edu) is Professor of Business Administration and Director for Latin America at Thunderbird School of Global Management in Glendale, Arizona. He served as Dean of the Business School at the American University of Shariah, U.A.E. and of the EGADE Business School at Monterrey Tec in Mexico. He was Founding Director of Standard Bank Group's (South Africa) Global Leadership Centre. He holds degrees in international economics from Princeton (B.A.) and North Carolina (Ph.D.). 